\title{
The State Socialist Mortality Syndrome
}

\author{
Elwood Carlson • Rasmus Hoffmann
}

Received: 12 March 2009/Accepted: 5 October 2010/Published online: 27 October 2010

(C) The Author(s) 2010. This article is published with open access at Springerlink.com

\begin{abstract}
Death rates for working-age men in European state socialist countries deviated from general improvements in survival observed in the rest of Europe during the 20th century. The magnitude of structural labor force changes across countries correlates with lagged increases in death rates for men in the working ages. This pattern is consistent with a hypothesis that hyper-development of heavy industry and stagnation (even contraction) of the service sector created anomic conditions leading to unhealthy lifestyles and self-destructive behavior among men moving from primary-sector to secondary-sector occupations. Occupational contrasts within countries similarly show concentration of rising male death rates among blue collar workers. Collapse of state socialist systems produced rapid corrections in labor force structure after 1990, again correlated with a fading of the state socialist mortality syndrome in following decades.
\end{abstract}

Keywords Working-age mortality - Labor force structure · Development policy $\cdot$ Europe $\cdot$ Anomie $\cdot$ State socialism

Electronic supplementary material The online version of this article (doi: $10.1007 / \mathrm{s} 11113-010-9192-\mathrm{z}$ ) contains supplementary material, which is available to authorized users.

\footnotetext{
E. Carlson $(\bowtie)$

Center for Demography and Population Health, Florida State University,

Tallahassee, FL 32306-2240, USA

e-mail: ecarlson@fsu.edu

R. Hoffmann

Department of Public Health, Erasmus Medical Center, Rotterdam, Netherlands

e-mail: r.hoffmann@erasmusmc.nl
} 


\section{Rising Working-Age Male Mortality}

A distinctive mortality trend appeared in Eastern Europe in the second half of the twentieth century (Cooper and Sempos 1984; Dupaquier 1984; Giersdorf and Schuler 1984; Bourgeois-Pichat 1985; Jozan 1989). Since it appeared only in state socialist countries, it aptly may be called the state socialist mortality syndrome (Valkovics 1984; Okolski 1987; Forster and Jozan 1990; Hoehn and Pollard 1991; Shkolnikov et al. 1998a). This syndrome had several hallmark features.

\section{Focus on Working-Age Men}

First, better public health service delivery throughout eastern Europe improved infant and child survival almost continuously after $1950 .{ }^{1}$ Second, survival of older adults remained stable or in many cases improved slightly throughout eastern Europe. This particularly reflected expansion of effective public health services and pension systems. Population coverage and the ratio of retirement income to working income increased just as rapidly in state socialist countries as in the western European region (Carlson and Watson 1990).

In contrast to success stories for young and old dependents, survival improvements at working ages (particularly for men) slowed and stopped during the first decade of state socialist rule in eastern Europe. ${ }^{2}$ Then death rates for working-age men began to increase throughout most of the region (Vacek 1969; Madai 1980; Cooper et al. 1984; Okolski 1985). Figure 1 shows ${ }_{5} \mathrm{M}_{\mathrm{x}}$ central mortality rates for Hungary over this period, the clearest example of the phenomenon.

For Hungarian men in their forties, 1995 death rates peaked nearly three times higher than 1960 death rates, before falling back during the decade after the collapse of state socialist governments to levels observed in the 1980s.

The negative survival trend appeared in every eastern European state socialist country except perhaps the German Democratic Republic, as shown in Fig. 2 for the probability of surviving from age 30 to $60\left({ }_{30} \mathrm{p}_{30}\right)$, ages where the state socialist mortality syndrome was concentrated. This trend did not appear in other European countries (Hoehn and Pollard 1991).

\footnotetext{
${ }^{1}$ Most state-socialist countries did introduce a non-standard definition of live births that produced underestimates of infant mortality in the range of 15 to 20 percent (Hoehn 1981; Anderson and Silver 1986), but these non-standard practices remained in effect for most of the second half of the century (Carlson and Tsvetarsky 1994) so trends in infant survival can be assessed despite biases in reported absolute infant mortality levels. One exception to the favorable overall trend involved temporary deterioration of infant mortality in the Soviet Union during the 1970s (Anderson and Silver 1989). This exception resulted from subordination of public health policies to economic development. A Soviet plan to depopulate hundreds of small villages shifted obstetric/gynecological nurses and polyclinics to centralized locations (Bernstam and Carlson 1988). Resulting post-neonatal mortality increases concentrated in these isolated rural areas of the Soviet Union (Velkoff and Miller 1995).

2 This analysis does not examine state socialist countries such as Cuba in other parts of the world, because the aim here is to examine contrasting paths of development and demographic change within the European culture area.
} 


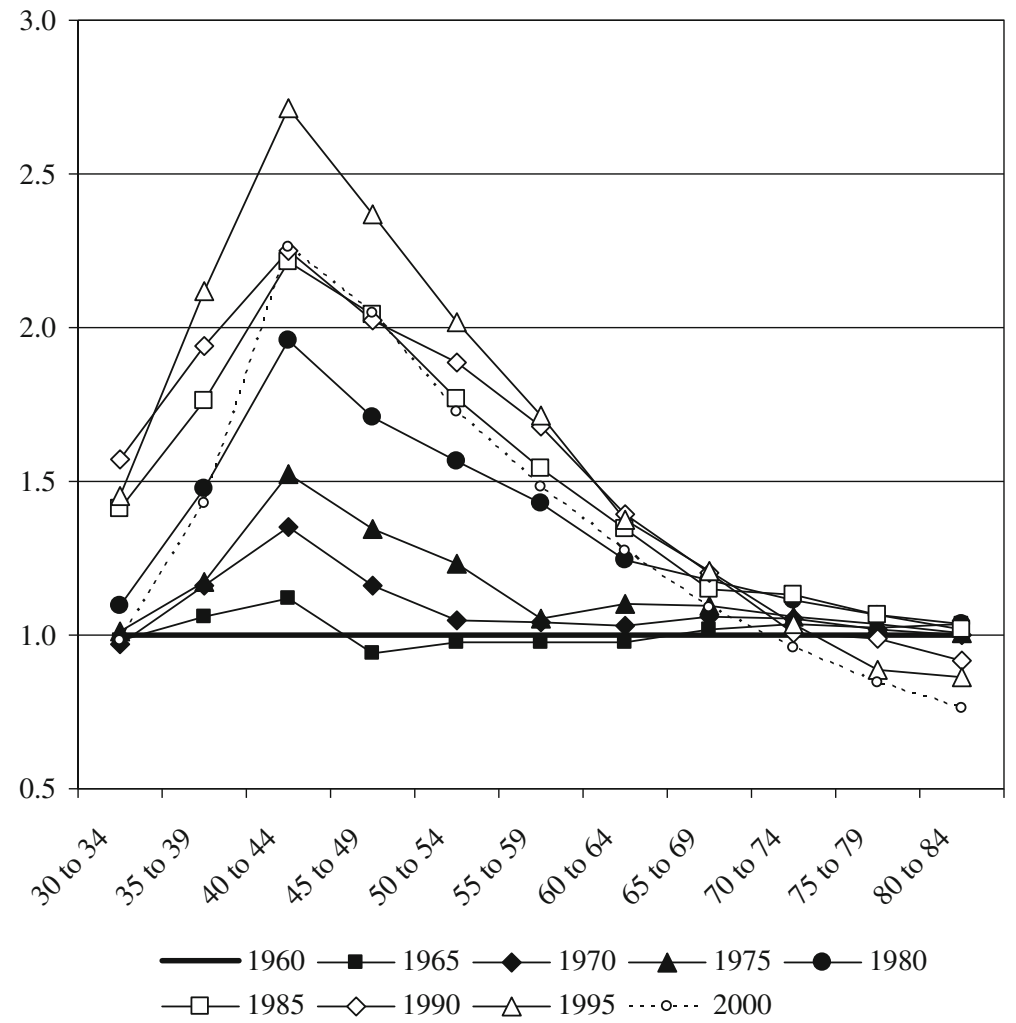

Fig. 1 Increase in death rates relative to 1960, Hungarian men. Source: Hungarian central mortality rates for men, ${ }_{5} \mathrm{M}_{\mathrm{x}}$, from Human Mortality Database (http://www.mortality.org)

Figure 2 also shows that the state socialist mortality syndrome began to disappear in all the former state socialist countries within the first decade after the collapse of state socialist governments around 1990.

\section{Age, Period, or Cohort Effects?}

Before considering explanations of the state socialist mortality syndrome based on contemporaneous social-structural context, we must ask whether long-term cohort explanations might better account for it. Particularly for Germany but also for other nations, Horiuchi (1983) pointed out that male cohorts born at the start of the 20th century experienced unusually high death rates in later life (from ages 45 or 50 onward) while women in the same cohorts did not. Drawing on related research from Japan (Okubo 1981) he attributed this to a lasting footprint of malnutrition in adolescence, experienced by these cohorts as they reached the critical years of puberty during the First World War. Boleslawski (1985) pointed out the existence of a similar long-term mortality effect for certain cohorts in Poland. Several writers (Compton 1985; Dinkel 1985; Anderson and Silver 1989) refer to this long-term 


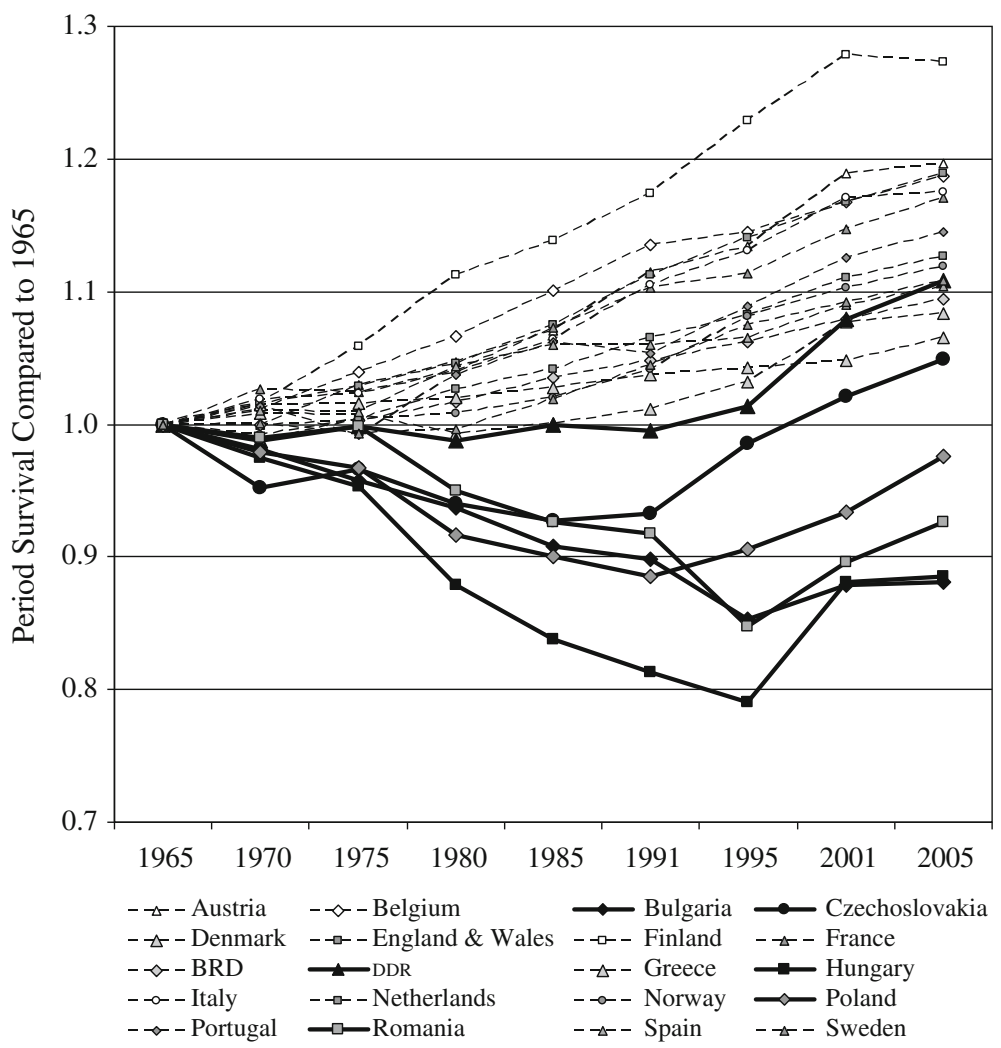

Fig. 2 Trends in survival $\left({ }_{30} \mathrm{p}_{30}\right)$ in Europe, $1965-2005$. Source: survival probabilities calculated from ${ }_{5} \mathrm{M}_{\mathrm{x}}$ central mortality rates in Appendices in Supplementary Material

effect as a possible explanatory factor for rising male death rates in Eastern Europe. Could the state socialist mortality syndrome have been a more widespread case of the passage of high-risk cohorts damaged by historical circumstances earlier in life?

The first piece of evidence against a cohort explanation comes from age trends in death rates. In most affected populations death rates increased first for men at older working ages between 45 and 60 during the 1960s and early 1970s (Carlson 1989; Carlson and Tsvetarsky 1992). Later in the 1970s and during the 1980s the syndrome moved downward to younger ages, beginning to affect men between ages 30 and 45. This downward shift is the opposite of the age trend that would be expected if specific high-risk cohorts were aging through the population over time.

We estimated age, period and cohort effects using logit transformations of ${ }_{5} \mathrm{M}_{\mathrm{x}}$ values from 1955 to 2005 for Hungarian men between ages 10 and 80, because they present the most drastic example of the state socialist mortality syndrome. ${ }^{3}$

The intrinsic estimator approach to separating age, period and cohort effects has been shown (Yang et al. 2004, 2008; Yang 2008) to be a more flexible, reliable and

\footnotetext{
3 Replication of calculations using cohort rather than period mortality rates do not reveal any significant difference in our results or conclusions.
} 
efficient model for estimating these joint effects than more traditional approaches, such as the constrained general linear model estimator which can produce very different estimates for different assumed or imposed constraints. The apc_ie procedure in Stata software identified row, column and diagonal effects within our age-by-year matrix of rates. The "row" or age effect averages mortality at each age across all observed years to produce a familiar typical age curve of mortality (see Table 1). We estimated age-effect ${ }_{5} \mathrm{M}_{\mathrm{x}}$ rates from $\beta_{\text {age }}$ coefficients produced by the Stata $a p c \_$ie procedure:

$$
{ }_{5} \hat{\mathrm{M}}_{\mathrm{x}}=e^{\left({ }^{\alpha+\beta_{\text {age }}}\right)} / 1+e^{\left(\alpha+\beta_{\text {age }}\right)} \cdot
$$

This age pattern ignores period trends and is based on data from all observed years considered together. The "column" or period effect averages mortality in each year across all ages. This average of logits of ${ }_{5} \mathrm{M}_{\mathrm{x}}$ across age groups is roughly equivalent to Schoen's (1970) geometric mean of mortality rates as a summary period measure of mortality. After an initial post-war decade of little change, the period effect increases dramatically for Hungarian men well into the 1990s, but then subsides in the post-state-socialist era, as shown in Table 1.

The Stata $a p c \_i e$ procedure estimates cohort effects net of the effects attributed to age and period factors. All three vectors of estimated effects appear in Table 1. However, the estimated cohort effects are problematic for answering our research question about the state socialist mortality syndrome. Since our matrix of rates is rectangular in age and year, estimated effects for the most recent cohorts are affected by progressive truncation of all but the youngest ages observed in the data. Similarly, we are only able to observe the earliest cohorts at the oldest ages. This truncation problem means that only the relatively flat middle portion of the cohort effect curve (where cohorts are observed across all considered ages) allows a reliable comparison to identify cohort effects. In the middle range where cohorts are directly comparable in terms of age ranges considered, this inductive approach to measuring cohort effects does not reveal variations capable of explaining the state socialist mortality syndrome. No clear cohort trend or deviations rivaling changes in the period effects appear in this flat middle section of the curve.

Horiuchi's older approach actually allows a more deductive answer to our question. Rather than inductively seeking cohort effects everywhere in the age-byyear matrix of rates, we look for such effects only where theoretically-grounded deduction tells us they ought to occur. Horiuchi isolated his high mortality cohort using ratios of age-specific mortality rates in each year, explaining that “...if a cohort experiences a relatively higher mortality schedule than its adjacent ones, low values of $\mathrm{k}(\mathrm{x})$ in older ages tend to be followed by high values of $\mathrm{k}(\mathrm{x})$ in younger ages, thereby resulting in a sequence of a dip and a peak...." (Horiuchi 1983. p. 81).

$$
\mathrm{k}(\mathrm{x})=\left[\ln \left({ }_{5} \mathrm{M}_{\mathrm{x}} /{ }_{5} \mathrm{M}_{\mathrm{x}-5}\right)\right] / 5 .
$$

Horiuchi's k-statistic estimates the rate of increase in death rates with increasing age. Constant values of $\mathrm{k}$ across the age spectrum would imply uniform exponential increase in mortality rates with age. Irregularities in this age pattern identify 
Table 1 Age, period and cohort effects ${ }^{\mathrm{a}}$ for Hungarian male mortality

\begin{tabular}{|c|c|c|c|c|}
\hline & Beta & Sigma & Z-score & Fitted logit \\
\hline Model intercept & -4.862 & 0.0132 & -367.5 & \\
\hline \multicolumn{5}{|c|}{ Row effect (midpoint of age groups) } \\
\hline 12.5 & -2.621 & 0.0377 & -69.6 & -7.483 \\
\hline 17.5 & -1.881 & 0.0359 & -52.4 & -6.742 \\
\hline 22.5 & -1.589 & 0.0360 & -44.1 & -6.450 \\
\hline 27.5 & -1.518 & 0.0361 & -42.1 & -6.380 \\
\hline 32.5 & -1.281 & 0.0361 & -35.5 & -6.142 \\
\hline 37.5 & -0.921 & 0.0361 & -25.5 & -5.782 \\
\hline 42.5 & -0.497 & 0.0361 & -13.8 & -5.358 \\
\hline 47.5 & -0.080 & 0.0361 & -2.2 & -4.942 \\
\hline 52.5 & 0.316 & 0.0361 & 8.8 & -4.545 \\
\hline 57.5 & 0.702 & 0.0362 & 19.4 & -4.160 \\
\hline 62.5 & 1.079 & 0.0362 & 29.8 & -3.782 \\
\hline 67.5 & 1.456 & 0.0362 & 40.3 & -3.405 \\
\hline 72.5 & 1.849 & 0.0361 & 51.3 & -3.012 \\
\hline 77.5 & 2.275 & 0.0359 & 63.3 & -2.587 \\
\hline 82.5 & 2.709 & 0.0368 & 73.7 & -2.153 \\
\hline \multicolumn{5}{|c|}{ Column effect (calendar years) } \\
\hline 1955 & -0.313 & 0.0299 & -10.5 & -5.175 \\
\hline 1960 & -0.293 & 0.0302 & -9.7 & -5.155 \\
\hline 1965 & -0.294 & 0.0303 & -9.7 & -5.155 \\
\hline 1970 & -0.175 & 0.0304 & -5.8 & -5.037 \\
\hline 1975 & -0.117 & 0.0304 & -3.9 & -4.979 \\
\hline 1980 & 0.077 & 0.0303 & 2.6 & -4.784 \\
\hline 1985 & 0.188 & 0.0303 & 6.2 & -4.674 \\
\hline 1990 & 0.290 & 0.0302 & 9.6 & -4.572 \\
\hline 1995 & 0.321 & 0.0301 & 10.6 & -4.541 \\
\hline 2000 & 0.134 & 0.0300 & 4.5 & -4.728 \\
\hline 2005 & 0.183 & 0.0316 & 5.8 & -4.678 \\
\hline \multicolumn{5}{|c|}{ Diagonal effect (median birth year of cohorts) } \\
\hline 1873 & 0.781 & 0.1140 & 6.9 & -4.081 \\
\hline 1878 & 0.736 & 0.0817 & 9.0 & -4.126 \\
\hline 1883 & 0.693 & 0.0678 & 10.2 & -4.169 \\
\hline 1888 & 0.613 & 0.0597 & 10.3 & -4.249 \\
\hline 1893 & 0.555 & 0.0543 & 10.2 & -4.306 \\
\hline 1898 & 0.460 & 0.0504 & 9.1 & -4.402 \\
\hline 1903 & 0.376 & 0.0472 & 8.0 & -4.486 \\
\hline 1908 & 0.251 & 0.0447 & 5.6 & -4.611 \\
\hline 1913 & 0.142 & 0.0424 & 3.4 & -4.720 \\
\hline 1918 & 0.051 & 0.0404 & 1.3 & -4.811 \\
\hline 1923 & 0.110 & 0.0384 & 2.9 & -4.752 \\
\hline
\end{tabular}


Table 1 continued

\begin{tabular}{lrrrr}
\hline & \multicolumn{1}{l}{ Beta } & Sigma & Z-score & Fitted logit \\
\hline 1928 & 0.166 & 0.0387 & 4.3 & -4.696 \\
1933 & 0.179 & 0.0387 & 4.6 & -4.683 \\
1938 & 0.171 & 0.0384 & 4.5 & -4.691 \\
1943 & 0.217 & 0.0379 & 5.7 & -4.645 \\
1948 & 0.132 & 0.0396 & 3.3 & -4.729 \\
1953 & 0.150 & 0.0414 & 3.6 & -4.711 \\
1958 & 0.096 & 0.0434 & 2.2 & -4.765 \\
1963 & -0.134 & 0.0459 & -2.9 & -4.996 \\
1968 & -0.361 & 0.0489 & -7.4 & -5.223 \\
1873 & -0.664 & 0.0528 & -12.6 & -5.525 \\
1978 & -0.768 & 0.0583 & -13.2 & -5.629 \\
1983 & -0.935 & 0.0665 & -14.1 & -5.796 \\
1988 & -1.105 & 0.0807 & -13.7 & -5.966 \\
1993 & -1.911 & 0.1256 & -15.2 & -6.772 \\
\hline
\end{tabular}

${ }^{a}$ Intrinsic Estimator effects from Stata $a p c_{-} i e$ procedure (see Yang et al. 2008) using rectangular matrix of $\operatorname{logit}\left({ }_{5} \mathrm{M}_{\mathrm{x}}\right)$ rates for $1955-2005$, ages $10-80$; period mortality rate data from Human Mortality Database

atypical age groups. If such anomalies track with a particular cohort as they grow older, we may speak of a high-mortality cohort in Horiuchi's sense.

We replicated Horiuchi's analysis using Hungarian ${ }_{5} \mathrm{M}_{\mathrm{x}}$ values. Consistent with Horiuchi's original hypothesis, Hungarian men born between 1901 and 1905 (who reached puberty during the First World War) do appear to produce higher $\mathrm{k}(\mathrm{x})$ values as they pass through successive ages in successive years. An even highermortality cohort born from 1906 to 1910 reached puberty in Hungary during the extremely hard years following the First World War, including the short-lived Hungarian Soviet Republic of Bela Kun in 1920 with its cataclysmic effects particularly in the rural population. Both these cohorts show Horiuchi's hypothesized mortality effects throughout their later lives. In addition, the birth cohort of 1925-1929 (males 20-24 in 1950, who thus entered puberty during the devastation of the Second World War) had consistently-elevated values of $\mathrm{k}(\mathrm{x})$ in Hungary as suggested by Compton and others. Finally, the birth cohort of 1940-1944 who reached puberty during the difficult period of the Hungarian Uprising in the mid1950s also may be a high-mortality cohort. The long-term cohort effect exists-but can it explain the state socialist mortality syndrome?

Horiuchi described a high-mortality cohort as producing "a sequence of a dip and a peak" in $\mathrm{k}(\mathrm{x})$ values. We can judge the cohort effect by comparing observed mortality patterns to those that would obtain if we erase this dip and peak. This is equivalent to estimating ${ }_{n} \mathrm{M}_{\mathrm{x}}$ for hypothetically affected cohorts as the geometric mean of adjacent rates for younger and older age groups. From these calculations, four or five percent of the observed ${ }_{5} \mathrm{M}_{60}$ for German men in 1964 represents higherthan-expected mortality, perhaps related as Horiuchi suggests to the long-term impact of war on a cohort. 


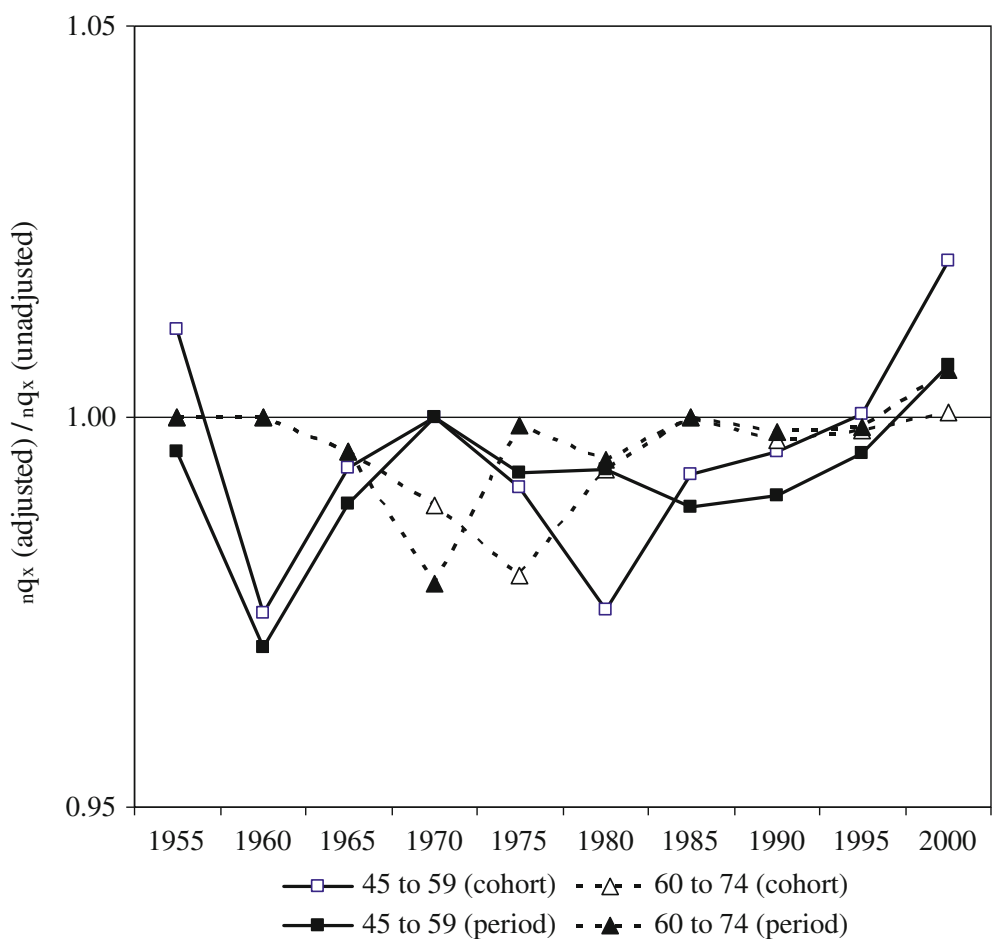

Fig. 3 Adjusted*/unadjusted probabilities of death for Hungarian men 45-59 and 60-74. ${ }_{5} \mathrm{M}_{\mathrm{x}}$ rates for suspected high-mortality cohorts re-estimated as geometric mean of rates for adjacent older and younger age groups in each year; ${ }_{5} \mathrm{q}_{\mathrm{x}}$ survival probabilities obtained as $\left[\left(2 n_{n} M_{x}\right) /\left(2+\left(n_{n} M_{x}\right)\right)\right]$. Survival probabilities $\left(1-{ }_{n} q_{x}\right)$ multiplied together to give ${ }_{n} q_{x}$ figures across wider age ranges. Source: period and cohort death rates for 5-year intervals and age groups from the Human Mortality Database (http://www.mortality.org)

Using the same logic, we adjust for the three exceptional Hungarian cohorts noted above by geometric interpolation of new ${ }_{5} \mathrm{M}_{\mathrm{x}}$ values ${ }^{4}$ in each year (linear interpolation using the logarithms of rates from adjacent younger and older age groups). How does this cohort effect translate into a possible explanation for rising death rates among working-age men in Hungary? How much of the upswing in mortality is accounted for as a cohort effect in the sense outlined above? We convert both observed and adjusted ${ }_{5} \mathrm{M}_{\mathrm{x}}$ values to ${ }_{5} \mathrm{p}_{\mathrm{x}}$ survival probabilities and take cumulative products of these ${ }_{5} \mathrm{p}_{\mathrm{x}}$ values to find actual and adjusted probabilities of surviving (or dying) in two age ranges-from 45 to 59 (the ages where the state socialist mortality syndrome is most apparent) and from 60 to 74 (early retirement ages during the state socialist epoch in eastern Europe). Figure 3 shows the impact in each considered year of our adjustment for high-mortality cohorts on the cumulative probability of dying between ages 45 and 59 and between ages 60 and 74. The hypothesized cohort effect does exist. Probabilities of dying drop by one or

\footnotetext{
${ }^{4}$ As illustrated in Fig. 3, we reach the same conclusion whether we use period-based or cohort-based ${ }_{5} \mathrm{M}_{\mathrm{x}}$ death rates from the Human Mortality Database.
} 
two percentage points after we adjust the higher mortality of cohorts whose adolescence came during extremely hard years. However, a shift of a percentage point or two in these death rates explains hardly any of the more than $300 \%$ period mortality increase observed as the state socialist mortality syndrome.

Moreover, these tiny effects of high-mortality cohorts were present throughout the period in question at one age or another, affecting overall survival in similar ways in every year considered. Both the older deductive Horiuchi method and Yang and Land's intrinsic estimator of age, period and cohort effects based on Stata's $a p c \_i e$ procedure show that cohort effects have little or nothing to contribute to an explanation of increases in the death rates of working-age men in the region. An explanation for the alarming period rise in mortality must be sought elsewhere.

\section{Explaining the State Socialist Mortality Syndrome}

Early explanations of the state socialist mortality syndrome focused on the health care delivery system (Deacon 1984; Feshbach 1982) and on lifestyles of the population, particularly diet (Cooper and Schatzkin 1982), alcohol consumption (Carlson and Watson 1990; Poikolainen 1995; Makala et al. 1997) and smoking (Cooper 1985; Jozan 1986).

In fact, health care delivery problems probably were not responsible for the working-age mortality increase (Ivanov and Echenique 2000). All explanatory efforts (McQueen and Siegrist 1982; Marmot et al. 1984; Kunitz 1987) must begin with the established clear age, sex and cause concentration, and must be consistent with it. People most responsive to good health care and most vulnerable to flaws in health care delivery (that is, infants and old people) did not experience the rising mortality trend. At the same time, people having least routine contact with health care and least vulnerability to problems in the health care delivery system (adult male workers) experienced most of the mortality increase. The health care explanation fails to fit these most basic facts of the phenomenon in question. Better health care delivery did play a role in improvements in old-age survival in the former state socialist countries after 1990 (Meslé 2004; Rychtaříková 2004) but these old-age survival improvements are not the subject of the present analysis. We are concerned with mortality trends at the heart of the working ages.

The lifestyle thesis (Cockerham 1997) is more plausible but more difficult to prove. This argument suggests that lifestyle changes produced mortality increase, without suggesting why the lifestyle changes themselves occurred. Risk-increasing behavior patterns have come to be recognized as manifestations of social disorganization and stress (Cornia and Paniccia 2000). In order to explain the state socialist mortality syndrome, then, one must identify special sources of such disorganization and stress that appeared in these countries in particular, that affected working-age men more than other population groups, and that produced effects predominantly in certain cause of death categories. Cockerham et al. (2002) suggested that lifestyle, health and survival may be linked to internalized passivity and other attitudinal consequences of state socialist ideologies. 
We expand on this idea by suggesting concrete structural changes in society that might account for prevalence of such attitudes and concentration of mortality effects among working-age men in particular. Building on existing studies, we offer a macro-structural perspective linking shifts in development policy and labor force structure to lifestyle change, health and mortality. We view policy initiatives of state socialist governments as the underlying source of stressful living conditions, pathological behavior and consequent mortality increase for men in the heart of the working ages. This hypothesis does not contradict other explanations of the rising mortality trend noted above. In fact, part of the usefulness of our exploratory macrostructural model stems from its ability to link together these other perspectives, particularly those related to specific causes of death, stress and lifestyle change (Meslé et al. 1993; Shkolnikov et al. 1998a; McKee and Shkolnikov 2001).

Cockerham (2005) has advocated closer attention to the possible links between social structure and survival. We believe that our reduced-form model linking social-structural conditions (Caselli 1991) directly to mortality trends is an appropriate step in this direction, because many of the intervening causal linkages already have been reasonably well established by existing research discussed above. By providing hypotheses about why certain mortality patterns arose in certain times and places, the present reduced-form model underpins other perspectives and contributes to a more complete understanding of a dramatic episode in demographic history. We test our explanation in two ways-first through comparisons across countries, and second through disaggregation of mortality patterns for occupational groups within specific countries. In both cases, we find patterns that would be expected if our explanation of the state socialist mortality syndrome has merit.

\section{Testing a Comparative Hypothesis}

Changing shares of the working population engaged in broad categories of activity reflect fundamental social-structural transformation (Smelser and Lipset 1967; Chandler 1980). We distinguish the secondary sector of an economy including heavy industry, construction, and electrical employment, from the primary sector including farming, fishing, and forestry. (Due to the "industrial" nature of mining, we follow other researchers and count miners in the secondary sector even though technically they work in the primary or extractive sector.) Both primary and secondary sectors are distinguished from the tertiary sector including transportation, commerce, personal service, clerical and managerial jobs, and professions.

We located labor force data by occupations for all considered countries at 5-year intervals from 1960 to 2005 and also for earlier dates of 1930 and 1950 to establish a baseline prior to the emerging consequences of state socialist development policies in eastern Europe (see Appendix B in Supplementary Material). The analysis omits women not only because the state socialist mortality syndrome appears almost exclusively among men, but also because definitions of what constitutes employment changed more for women (particularly with respect to agriculture) over the course of the 20th century. While detailed occupational definitions vary across countries, occupational assignment to primary, secondary 
and tertiary sectors exhibits a high degree of standardization both across countries and over time. In all cases, the three sectors are constructed by summing consistently-defined occupational subgroups as identified for various years in annual Yearbooks of the International Labor Organization, Eurostat and the United Nations. Consistency checks demonstrate that the figures reported in these sources generally agree with one another. The International Standard Industrial Classification (ISIC) used consistently in all these sources provides a cross-national basis for assigning occupational groups to the three basic sectors of every country's labor force.

The relative sizes of these structural sectors parallel levels of urbanization (Shandra et al. 2003), GNP per capita, standards of living, and similar dimensions of social and economic development. While social characteristics of individuals including social class (Daric 1951; Pamuk 1985; Klinger 1987; Mare 1990; Feinstein 1993; Valkonen 1993); education (Kunst and Mackenbach 1994; Preston and Elo 1995; Shkolnikov et al. 1998b); or rural versus urban residence (Vielrose 1984; Jozan 1986) can provide powerful descriptors of mortality differences, the distribution of these characteristics of individuals stems from the underlying structure and relative size of the basic productive sectors of an economy (Stocks 1938; Smelser and Lipset 1967). We examine two orthogonal measures of the relative size of these labor force sectors: the ratio of secondary-sector to tertiarysector jobs $(\mathrm{S} / \mathrm{T})$, and the ratio of both of these sectors combined to the primary sector of the economy $((\mathrm{S}+\mathrm{T}) / \mathrm{P})$.

\section{European Sub-Regions for Comparative Analysis}

The twentieth century witnessed fundamental structural transformation of European countries. Moore (1945, p. 17) described the continent in terms of an urbanindustrial core in the northwest ringed by a less-developed periphery in the east and south-a demarcation that is re-emerging in the 21 st century and that as illustrated below continues to capture statistically significant and important economic and demographic contrasts within Europe ${ }^{5}$ :

If one were to draw a circle on a map of Europe, with a center in the North Sea off the English coast and with a radius of some 800 miles, the arc dividing the European continent would approximate the boundary line between the relatively prosperous industrial economies of the North and West and the

\footnotetext{
5 Changing national boundaries produce some variation in the list of countries. The reunification of Germany reduced the number of countries in the core by one, but since we concentrate on Europe's periphery this has little effect on our results. The split of Czechoslovakia into Slovakia and the Czech Republic increased the number of countries in the state socialist periphery, but we recombine labor force and mortality figures for the two new states and work with a single distribution for all of the former Czechoslovakia even after the formal separation. A similar concatenation of data for successor states of the former Yugoslavia also was attempted, though there is less certainty about some of the data used in this Yugoslav reconstruction. For the three most recent dates in our series we experimented with the alternative of including data for Serbia, Croatia and Slovenia separately (with other fragments of the former Yugoslavia omitted). These alternative lists of countries do not yield different substantive results in any significant respect.
} 
relatively underdeveloped and predominantly agrarian economies of the South and East. (Moore 1945, p. 17).

Core countries inside Moore's circle (Denmark, France, Germany, the UK, Belgium, the Netherlands and Switzerland) already had experienced considerable contraction of agriculture by the early twentieth century. They clearly differed as a group from countries outside the circle (Albania, Bulgaria, Finland, Greece, Hungary, Poland, Portugal, Romania, Spain and Yugoslavia) in levels of manpower distributed across sectors of the economy. Data were not available for Albania for most years, nor for the former Soviet Union for the early postwar period, so neither of these countries appear in this analysis.

Several countries are split by Moore's circle. Assessing the level and trend of urban-industrial development in these countries individually, two (Austria and Sweden) can be assigned to the core at mid-century. The others (Czechoslovakia, Italy and Norway) should be grouped with the periphery, though a more refined model would assign the Czech Republic (inside Moore's circle) to the core and Slovakia (outside the circle) to the periphery as of 1950. Additionally, some countries that fall completely inside the circle, notably Ireland, clearly must be shifted from core to periphery in terms of urban-industrial status as of midcentury.

\section{The Retreat from Agriculture: Uniformity in Europe's Periphery}

Moore's distinction between Europe's core and periphery captures an enduring and statistically significant contrast in the share of men working in primary-sector occupations (agriculture, forestry and fishing). In 1960, for example, $40 \%$ of men in periphery countries worked in primary occupations while only $16 \%$ of men in core countries held such jobs. By 2005, these percentages had declined to 11 and 4\% respectively, still a statistically significant difference. Most of the variance across Europe in "percent primary" is captured in all years by this core-periphery contrast, which remained statistically significant $(p<0.01)$ for all years considered.

All state socialist countries with the exception of the German Democratic Republic appeared in Europe's periphery. For this reason and because the exodus from agriculture produced much larger sectoral shifts in the labor force of periphery countries, remaining analyses concentrate on Europe's periphery countries. Including core countries un-balances the research design with respect to the statesocialist/non-state-socialist contrast, and also would mix together countries at quite different stages of development.

Proportions of men with primary-sector jobs did not vary significantly between state-socialist and non-state-socialist regions of Europe's periphery in any considered year, although the collapse of former state-socialist economies after 1990 hit their agricultural sectors particularly hard. All European periphery countries essentially underwent the 20th-century exodus from agriculture together as a homogenous region. State socialist economic policy did not accelerate the flow out of agricultural employment, beyond that seen in market capitalist countries of the periphery with their roughly matching proportions employed in agriculture at 
mid-century. This homogeneity in "percent primary" throughout Europe's periphery allows us to concentrate on comparisons of the sectoral distribution of the remaining male labor force outside the primary sector.

\section{Contrasts in the Ratio of Secondary to Tertiary Sector Workers}

State socialist development policies mainly influenced the destination of workers leaving agriculture, affecting the balance between the secondary and tertiary sectors and, we believe, producing changes that induced stress and self-destructive behavior for working-age men, particularly in certain occupations. Kornai $(1959 ; 1982 ; 1992)$ succinctly summarizes how state socialist economies gradually became more and more "bottom-heavy," concentrating in the primary production processes, producing less and less final consumer output from more and more raw material inputs (Carlson and Bernstam 1992). As a predictable corollary of the gradual settling of the economy toward primary extractive and low-level manufacturing at the expense of consumable output, the service sector in state socialist economies atrophied by comparison with the market capitalist countries of Europe's periphery. As workers left agriculture, state socialist planners and the momentum of state socialist economic evolution steered them toward heavy industrial jobs rather than service occupations (Conner 1991). A ratio of secondary-sector to tertiary-sector employment in each country's labor force captures this development contrast at various points during the century.

At mid-century the labor force effects of distinctive development policies had not yet appeared in state socialist countries. Figure 4 shows the ratio of secondarysector to tertiary-sector jobs (the S/T ratio) for countries in Europe's periphery, regressed on a simple state-socialist versus market-capitalist dichotomy in successive years. This dichotomy was not a significant predictor of the S/T ratio in either 1930 or 1950, confirming the homogeneity of Europe's periphery prior to the advent of the state socialist epoch.

Starting in the 1960s, however, the S/T ratio shot up dramatically throughout the state socialist half of Europe's periphery. At the same time, in the market capitalist periphery countries this ratio began to fall soon after mid-century (just as it did in the mostly market capitalist European core countries). Both these trends are illustrated in Fig. 4. While the state socialist versus market capitalist dichotomy captured less than $2 \%$ of all variation in the $\mathrm{S} / \mathrm{T}$ ratio in 1950 , this single coefficient using a single degree of freedom already captured about $41 \%$ of all variation in the ratio by 1960 , and nearly $80 \%$ of all variation by 1985 . The predictive power of this dichotomy then dropped dramatically after the collapse of state socialist governments in 1990, though remaining significant through 2005. The contrast in S/T ratios between state socialist and market capitalist countries in Europe's periphery appeared despite their great similarity noted above in the transition out of agriculture, making them reasonable approximations of an experimental and a control group of countries, respectively. The experimental condition present in the former group but absent in the latter group was state socialist development policy. 


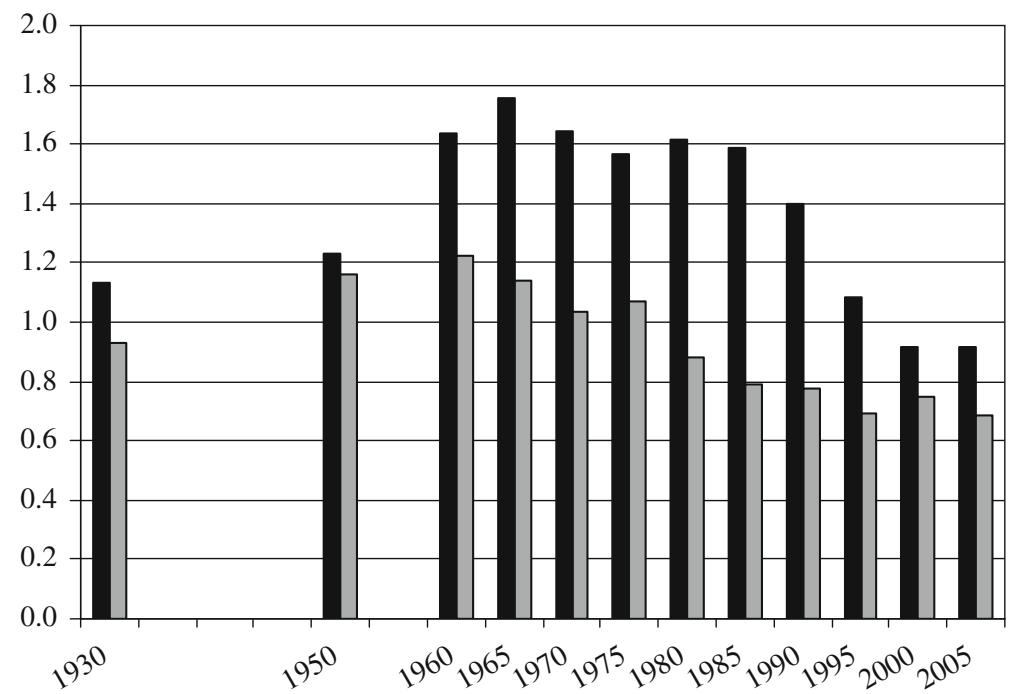

State Socialist $\square$ Market Capitalist

Fig. 4 Ratio of secondary/tertiary jobs. State socialist versus market capitalist countries in Europe's periphery. Source: OLS regression of ratio of men in secondary versus tertiary occupations on region (data from Appendix Table B in Supplementary Material). State Socialist countries in the European periphery include Bulgaria, Czechoslovakia, Hungary, Poland, Romania and Yugoslavia. After the breakup of Czechoslovakia we recombine Slovak and Czech data weighted by population to reconstruct rates for a consistent territorial unit. After the breakup of Yugoslavia, we experimented with alternative inclusion of Serbia, Croatia and Slovenia, and with reconstructing synthetic Yugoslav data from these three components. Market Capitalist countries in the European periphery include Finland, Greece, Ireland, Italy, Norway, Portugal and Spain. This classification applies to all subsequent figures

\section{Structural Origin of a Special Risk Group}

What do development policy and labor force structure have to do with mortality? We suggest that forced rapid expansion of heavy industry and restrictions on the service sector created a highly anomic environment for the many predominantly male workers leaving agriculture. Volgyes (1980, p. 443) succinctly described the case of Hungary as it witnessed the largest proportionate occupational shift in the region from agriculture to industrial employment, followed in succeeding years by the largest proportionate increase in death rates for middle-aged men. ${ }^{6}$ During this period of rapid economic transformation between 1950 and 1965, the Hungarian labor force included 700,000 people who commuted back and forth from villages to urban employment daily and anther 450,000 who commuted weekly or less often. The "black trains" that carried them to and from the villages were notorious scenes of mass drunkenness and general suspension of the conventions of ordinary daily life. Notably, in the beginning of the 1950s most of the commuters were middle-

\footnotetext{
${ }^{6}$ We also note in this connection that the state socialist country with the smallest shift from agricultural to industrial employment, the German Democratic Republic, also showed the smallest increase in working-age male mortality.
} 
aged men (Volgyes 1980, p. 449). Not surprisingly, then, mortality increases occurred in rural as well as urban areas, since many rural residents were actually commuting to and working in the new urban industrial districts (Andorka and Harcsa 1983).

In the case of Hungary and her state socialist neighbors approximating an experimental group, these labor force movements responded largely to push factors. By contrast, in the market capitalist countries of the European periphery such as Finland, Greece, Spain or Italy approximating a control group, manpower flows of similar magnitude responded to pull factors from spontaneous growth of the service sector as well as creation of new industrial jobs.

Organized state socialist expansion of factory employment quickly outpaced the ability of the social environment to assimilate the new factory workers. The service sector as a whole was severely constrained by state socialist development policyin Czechoslovakia this sector of the labor force actually shrank in absolute terms in the immediate postwar period, even as industry expanded rapidly. Migrants who eventually escaped the disruptions of long-term mass commuting lived in vast, anonymous clusters of identical multistorey apartment buildings. The Hungarians called them "lakoteleps," literally archipelagos of apartments rising out of the older urban sea around them, but the architectural form is familiar throughout all the countries of the state socialist bloc. Service facilities in these vast anonymous hives were standardized, elementary, and state-owned and operated. Working-age male migrants entering this new social landscape found themselves structurally isolated both at home and at work. The social controls of village life disappeared. Anomie generated by state socialist development policies focused self-destructive behavior on men in the middle working ages and transformed them into a special risk group for rising death rates.

\section{Mortality Trends Correlate with LF Structure in Europe's Periphery}

Just as the dichotomy of state socialist versus market-capitalist countries within Europe's periphery became a very powerful predictor of labor force differences in the second half of the twentieth century, this same dichotomy also became a powerful predictor of diverging death rates among men in the heart of the working ages. ${ }^{7}$ Figure 5 shows no significant difference in death rates distinguishing these regions from each other as late as 1960. During the remainder of the century, however, death rates for working-age men declined throughout the market capitalist half of the periphery while death rates increased rapidly throughout the state socialist half. This statistically significant contrast peaked shortly after the collapse of the state socialist governments, and then gradually began to fade away in the decade that followed.

The contrast in mortality trends between the state socialist and market capitalist halves of Europe's periphery resembles the contrast shown in Fig. 4 for divergent

\footnotetext{
7 All probabilities of dying, ${ }_{15} q_{45}$, result from converting observed central mortality rates ${ }_{5} M_{x}$ into survival probabilities ${ }_{5} p_{x}$ for five-year age groups, multiplying together all ${ }_{5} p_{x}$ values in the relevant age range, and then subtracting the result from unity to estimate a cumulative ${ }_{15} q_{45}$ probability of dying. These cumulative probabilities are shown in Appendix Table C in Supplementary Material.
} 


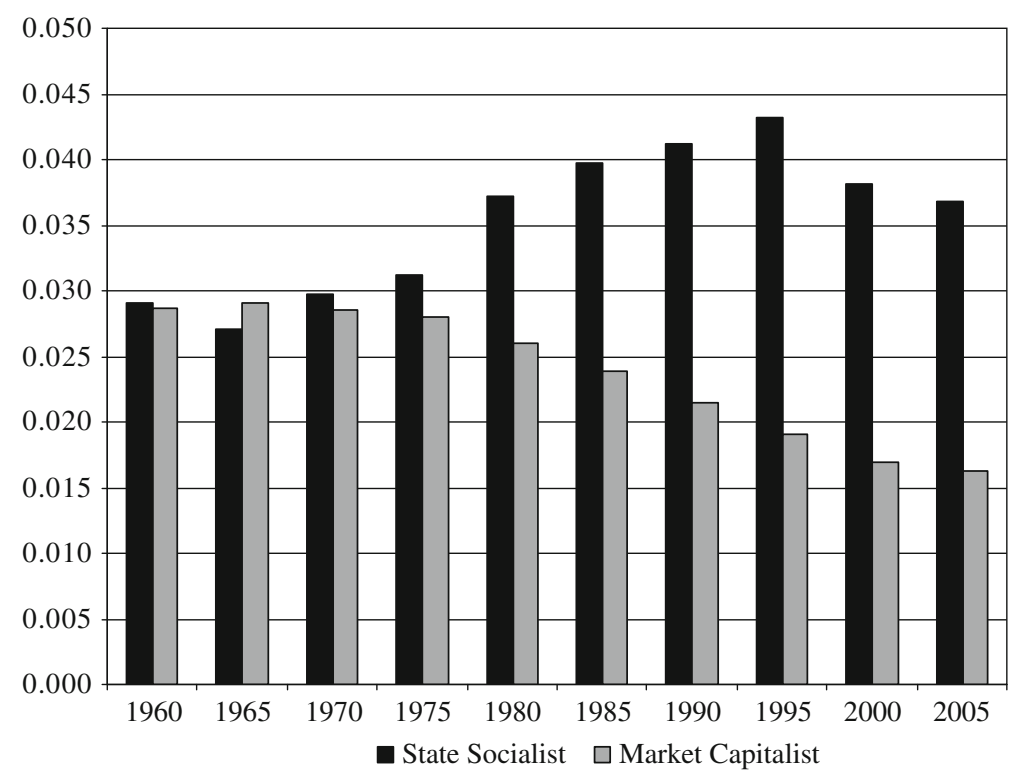

Fig. 5 Working-age male mortality $\left({ }_{15} q_{45}\right)$. State socialist versus market capitalist countries in Europe's periphery. Source: OLS regression of ${ }_{15} q_{45}$ on region, as for Fig. 4

occupational trends in the same regions, except that Figs. 4 and 5 taken together suggest a lag of some years for emergence of the state-socialist mortality syndrome following the appearance of the $\mathrm{S} / \mathrm{T}$ ratio contrast between regions. A lag of up to a decade from the time that state socialist development policies first produced a distinctive secondary/tertiary overload, to accumulating social and behavioral consequences, and finally to the outcome of rising death rates, seems plausible.

The surface appearance of a parallel between structural labor force changes and subsequent mortality trends suggests a more rigorous statistical model to test the association across time between these phenomena. The first step in this process more rigorously assesses the link between mortality trends and the state socialist/ market capitalist dichotomy in the European periphery. We regress death rates on this dichotomy for countries in Europe's periphery between 1960 and 2005, accounting for country-specific influences through a fixed-effects panel regression design. That is, in addition to the state socialist/market capitalist dichotomy, our predictors also include a measure of each country's death rate at a previous time. Formula $3 \mathrm{a}$ shows the period probability of dying between ages 45-60 at time $t+n$ as a function of the equivalent probability of dying $n$ years earlier and a zero/ one variable identifying state socialist periphery countries:

$$
{ }_{15} q_{45}^{t+n}=\alpha+\beta_{1}\left({ }_{15} q_{45}^{t}\right)+\beta_{2}(s s)+\varepsilon,
$$

where $s s=1$ for state socialist countries and $s s=0$ for market capitalist countries, $t$ represents time, and $q$ is the probability of dying. The coefficient for the fixedeffects lagged $q_{x}$ term on the right side in Eq. 3a dominates fixed-effects panel regression models and is generally substantively uninteresting. Models including 
Table 2 State socialist/market capitalist dichotomy predicts mortality changes

\begin{tabular}{|c|c|c|c|c|c|c|}
\hline & Intercept & $\beta$ (state socialist) & $\sigma_{\beta}$ & $t(\beta)$ & $\operatorname{Pr}>t$ & Adjusted $R^{2}$ \\
\hline \multicolumn{7}{|c|}{ Five-year change-score regression for ${ }_{15} q_{45}(n=107)$} \\
\hline$\Delta\left({ }_{15} \mathrm{q}_{15}\right)$ & -0.00013 & -0.00009 & $9.44 \mathrm{E}-05$ & -0.99 & 0.322 & -0.0001 \\
\hline$\Delta\left({ }_{15} \mathrm{q}_{30}\right)$ & -0.00034 & 0.00039 & 0.000225 & 1.74 & 0.085 & 0.0185 \\
\hline$\Delta\left({ }_{15} \mathrm{q}_{45}\right)$ & -0.00138 & 0.00224 & 0.000556 & 4.04 & 0.000 & 0.1251 \\
\hline$\Delta\left({ }_{15} \mathrm{q}_{60}\right)$ & -0.00547 & 0.00454 & 0.001533 & 2.96 & 0.004 & 0.0676 \\
\hline \multicolumn{7}{|c|}{ Ten-year change-score regression for ${ }_{15} \mathrm{q}_{45}(n=95)$} \\
\hline$\Delta\left({ }_{15} \mathrm{q}_{15}\right)$ & -0.00023 & -0.00016 & 0.00014 & -1.20 & 0.234 & 0.0045 \\
\hline$\Delta\left({ }_{15} \mathrm{q}_{30}\right)$ & -0.00070 & 0.00099 & 0.00036 & 2.78 & 0.007 & 0.0663 \\
\hline$\Delta\left({ }_{15} \mathrm{q}_{45}\right)$ & -0.00307 & 0.00542 & 0.00091 & 5.95 & 0.000 & 0.2660 \\
\hline$\Delta\left({ }_{15} \mathrm{q}_{60}\right)$ & -0.01164 & 0.01048 & 0.00225 & 4.67 & 0.000 & 0.1796 \\
\hline
\end{tabular}

Source: original panel regression calculations from data in Appendices in Supplementary Material $\Delta\left({ }_{15} q_{x}\right)={ }_{15} q_{x}^{t+n}-{ }_{15} q_{x}^{t}$ (equivalent to fixed-effect lag with $q_{x}$ at time $t$ on right side of equation)

such lagged dependent variables also yield absurdly high estimates of explained variance dominated by the relative stability of the dependent variable across time, so realistic estimates of the explanatory power of the other independent variables in the model are less obvious. We prefer to transform this lagged fixed-effects model into an equivalent change-score model with all the same information, by shifting the survival probability at the earlier time point to the left side of the equation as in Formula 3b:

$$
{ }_{15} q_{45}^{t+n}-{ }_{15} q_{45}^{t}=\alpha+\beta(s s)+\varepsilon .
$$

Table 2 presents results of two OLS regression models considering mortality change first over a 5-year period and then over a 10-year period. In each case we regress observed mortality changes in four age ranges on the state socialist dummy variable across countries and years, as shown in Table 2.

The 5-year models include observations for all European periphery countries at 5-year intervals from 1960 to 2000. (The requirement of two mortality estimates 5 years apart for the dependent change-score variable means that 2005 is not considered as a value for time $t$, although 2005 death rates are included in the calculations when $t$ is year 2000.) For the same reason, the 10-year models include values of $t$ at 5-year intervals from 1960 to 1995.

The negative intercepts of these models estimate the average change in ${ }_{15} \mathrm{q}_{\mathrm{x}}$ (a slight decline for each 15-year age range) over considered years in market capitalist periphery countries. (When ss $=0$ the $\beta$ term drops out of Formula 3.) The fact that the generally positive beta coefficients for the state socialist dummy variable often exceed the magnitude of these intercepts (yielding a positive rather than negative result when intercept and beta coefficient are combined in each model) illustrates the rising rather than declining trend in ${ }_{15} \mathrm{q}_{\mathrm{x}}$ characteristic of the state socialist mortality syndrome. These panel regression results confirm the impression emerging from Fig. 5 that the state socialist/market capitalist dichotomy captured a significant divergence of mortality trends in the two halves of the European 
Table 3 Ratio of secondary to tertiary workers predicts mortality changes

\begin{tabular}{|c|c|c|c|c|c|c|}
\hline & Intercept & $\beta$ (S/T ratio) & $\sigma_{\beta}$ & $t(\beta)$ & $\operatorname{Pr}>t$ & Adjusted $R^{2}$ \\
\hline \multicolumn{7}{|c|}{ Five-year change-score regressions $(n=107)$} \\
\hline$\Delta\left({ }_{15} \mathrm{q}_{15}\right)$ & -0.00021 & 0.00003 & 0.00011 & 0.31 & 0.756 & -0.0085 \\
\hline$\Delta\left({ }_{15} \mathrm{q}_{30}\right)$ & -0.00128 & 0.00094 & 0.00024 & 3.87 & 0.000 & 0.1157 \\
\hline$\Delta\left({ }_{15} \mathrm{q}_{45}\right)$ & -0.00433 & 0.00331 & 0.00060 & 5.55 & 0.000 & 0.2176 \\
\hline$\Delta\left({ }_{15} \mathrm{q}_{60}\right)$ & -0.01300 & 0.00801 & 0.00163 & 4.90 & 0.000 & 0.1771 \\
\hline \multicolumn{7}{|c|}{ Ten-year change-score regressions $(n=95)$} \\
\hline$\Delta\left({ }_{15} \mathrm{q}_{15}\right)$ & -0.00032 & 0.00002 & 0.00016 & 0.15 & 0.879 & -0.0104 \\
\hline$\Delta\left({ }_{15} \mathrm{q}_{30}\right)$ & -0.00238 & 0.00171 & 0.00038 & 4.49 & 0.000 & 0.1678 \\
\hline$\Delta\left({ }_{15} \mathrm{q}_{45}\right)$ & -0.00949 & 0.00711 & 0.00096 & 7.42 & 0.000 & 0.3624 \\
\hline$\Delta\left({ }_{15} \mathrm{q}_{60}\right)$ & -0.02541 & 0.01486 & 0.00236 & 6.29 & 0.000 & 0.2886 \\
\hline
\end{tabular}

Source: original panel regression calculations from data in Appendices in Supplementary Material $\Delta\left({ }_{15} q_{x}\right)={ }_{15} q_{x}^{t+n}-{ }_{15} q_{x}^{t}$ (equivalent to fixed-effect lag with $q_{x}$ at time $t$ on right side of equation)

periphery in the late 20th century, because the regression coefficient for the state socialist variable is highly significant.

Since Fig. 4 creates an equally strong impression that the state socialist/market capitalist dichotomy also captures a significant divergence in labor force trends in these same countries during the same decades, the next logical step is to replace the state socialist dummy variable in Formula $3 \mathrm{~b}$ with a direct measure of labor force trends - that is, the ratio of secondary to tertiary workers in each economy at each date. Table 3 shows that the beta coefficients for the S/T ratios also are uniformly positive in all considered age ranges and for both sets of models, indicating that higher $\mathrm{S} / \mathrm{T}$ ratios predicted more mortality increase (or less mortality decline) across considered countries and years.

In both 5- and 10-year lag models the effect of the S/T ratio on mortality change is not significant for men 15-30 years old, but highly significant for all older age ranges. Both the t-scores and the adjusted $R^{2}$ values for these equations are strongest for the 45-60 age range, where the state socialist mortality syndrome concentrated. This result is hardly surprising, since the $\mathrm{S} / \mathrm{T}$ ratio itself is strongly predicted by the state socialist/market capitalist dichotomy.

The final piece of this puzzle, then, is to include both the direct effect of the $\mathrm{S} / \mathrm{T}$ ratio and the state socialist/market capitalist contrast in the same model. For good measure, we also include the $(\mathrm{S}+\mathrm{T}) / \mathrm{P}$ ratio of non-primary to primary occupations, to illustrate that this factor was generally unrelated to mortality trends throughout the European periphery. Table 4 shows results of these multivariate change-score panel regressions, concentrating on the ${ }_{15} \mathrm{q}_{45}$ age range at the heart of the state socialist mortality syndrome where preceding models showed the strongest effects.

This table reveals that whether we consider 5- or 10-year mortality changes, the direct effect of the state socialist/market capitalist distinction seen in Table 2 is almost completely explained in terms of the direct effect of the $\mathrm{S} / \mathrm{T}$ ratio seen in Table 3. In other words, changes in the ratio of secondary to tertiary sector workers accounts for almost all of the effect of the dichotomy, leaving little or nothing to be 
Table 4 Ratio of secondary to tertiary workers explains state socialist effect on mortality

\begin{tabular}{|c|c|c|c|c|}
\hline & Coefficient & Std. Error & $t$ & $\operatorname{Pr}>t$ \\
\hline \multicolumn{5}{|c|}{ Five-year change-score regression for $\Delta_{15} q_{45}(n=107)$} \\
\hline Intercept & -0.00356 & 0.00121 & -2.95 & 0.004 \\
\hline $\mathrm{S} / \mathrm{T}$ ratio & 0.00267 & 0.00092 & 2.91 & 0.004 \\
\hline$(\mathrm{S}+\mathrm{T}) / \mathrm{P}$ ratio & -0.00005 & 0.00009 & -0.60 & 0.552 \\
\hline State-socialist & 0.00058 & 0.00072 & 0.80 & 0.428 \\
\hline \multicolumn{5}{|c|}{ Ten-year change-score regression for $\Delta_{15} q_{45}(n=95)$} \\
\hline Intercept & -0.00605 & 0.00200 & -3.03 & 0.003 \\
\hline $\mathrm{S} / \mathrm{T}$ ratio & 0.00459 & 0.00152 & 3.02 & 0.003 \\
\hline$(\mathrm{S}+\mathrm{T}) / \mathrm{P}$ ratio & -0.00028 & 0.00016 & -1.72 & 0.090 \\
\hline State-socialist & 0.00208 & 0.00124 & 1.68 & 0.097 \\
\hline
\end{tabular}

Source: original panel regression calculations from data in Appendices in Supplementary Material $\Delta\left({ }_{15} q_{x}\right)={ }_{15} q_{x}^{t+n}-{ }_{15} q_{x}^{t}$ (equivalent to fixed-effect lag with $q_{x}$ at time $t$ on right side of equation)

explained by other factors. Labor force change appears to be a necessary and sufficient condition for producing the state socialist mortality syndrome. The $(\mathrm{S}+\mathrm{T}) / \mathrm{P}$ ratio, measuring the extent of the exodus from agriculture, fails to explain anything significant about observed mortality trends in these decades.

We have shown, then, that not only does the state socialist/market capitalist dichotomy capture an important divergence in mortality trends within developing European countries, but that this mortality syndrome can be further specified as related directly to the observed contrast in labor force trends between these two halves of Europe's periphery. All these facts and patterns are consistent with our hypothesis that state socialist development policies constituted something like an "experimental condition" that affected living arrangements, behaviour, health, and ultimately survival, particularly for men at the heart of the working ages.

\section{Testing an Internal Disaggregative Hypothesis}

Turning from international comparison to national case studies, a different hypothesis also can be derived from the theoretical linkage of state socialist development policy and rising working-age male mortality. If the shift of workers from agricultural labor to service-starved industrial districts is the key to the acquired frailty of this specific population group, then the mortality increase ought to have been concentrated in certain segments of the population.

Specifically, nearly all of the rural-urban commuters and migrants made their way into manual (blue-collar) occupations. Very few persons leaving village agriculture moved into non-manual employment as doctors, lawyers, scientists or government officials. Therefore the mortality increase should have been concentrated among manual workers, leaving the non-manual workers who had not experienced this wrenching alteration of their lives relatively immune to the phenomenon. 


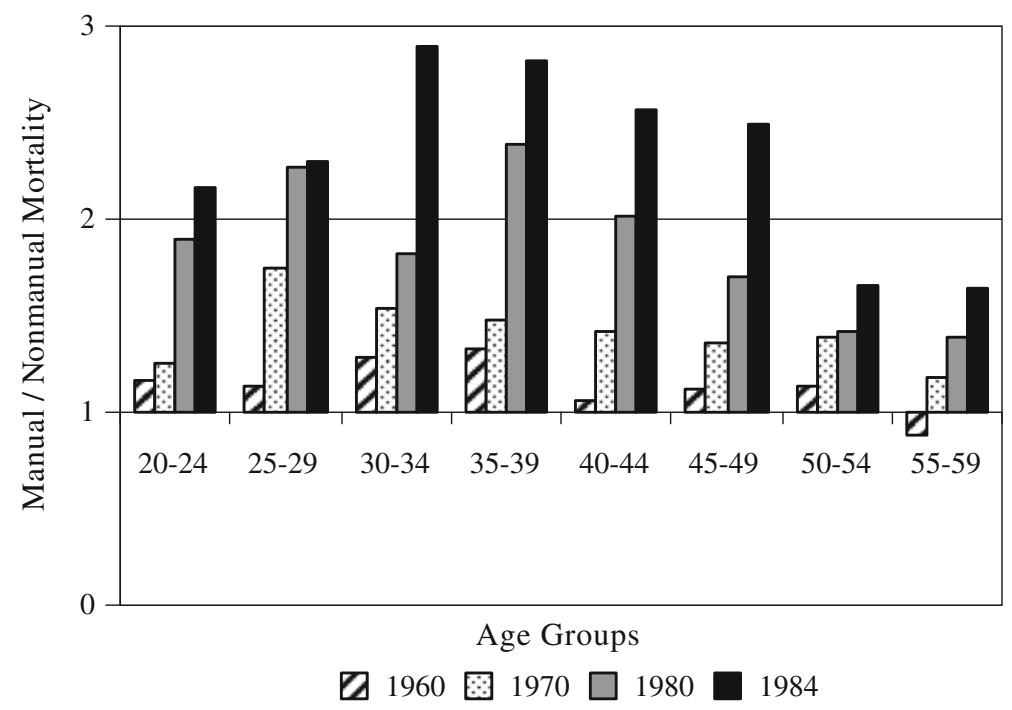

Fig. 6 Excess manual mortality-Hungary. Source: data from Carlson 1989. Concentration of rising Hungarian mortality among manual workers. Sociology and Social Research 73(3):119-128

This is precisely the case, as has been established in previous research. In both Hungary (Madai 1980; Compton 1985; Carlson 1989; Jozan 1989) and Bulgaria (Griva and Sugareva 1984; Golemanov et al. 1984; Minev et al. 1990; Carlson and Tsvetarsky 1992) virtually all of the increase in working-age male mortality occurred exclusively among manual workers. In both countries, non-manual earners were essentially immune to the rising risk.

The results of these trends in Hungary are illustrated in Fig. 6. In 1960, when the state socialist mortality syndrome had barely begun to appear, manual workers had age-specific death rates almost identical to those for non-manual workers. Over the next decade, a massive mortality surplus began to appear among older working-age men in manual occupations, while death rates for non-manual workers in the same ages remained virtually unchanged. By 1980 rising death rates spread downward to younger working ages, mirroring expansion of social dislocations downward into these same younger ages.

In almost identical fashion, working-age mortality for manual workers in Bulgaria also increased as shown in Fig. 7, while for non-manual workers these death rates hardly changed at all.

Similar results recently have appeared for Latvia and other selected areas of the former Soviet Union that possess adequate statistics to examine these patterns (Andreev et al. 2009). Again, mortality increases concentrated disproportionately among blue-collar workers, leaving white-collar workers with little increase (or even observed decreases) in death rates. Similarity of these results across countries suggests that concentration of rising working-age mortality among manual workers characterized the entire region, exactly as predicted by our explanation. 


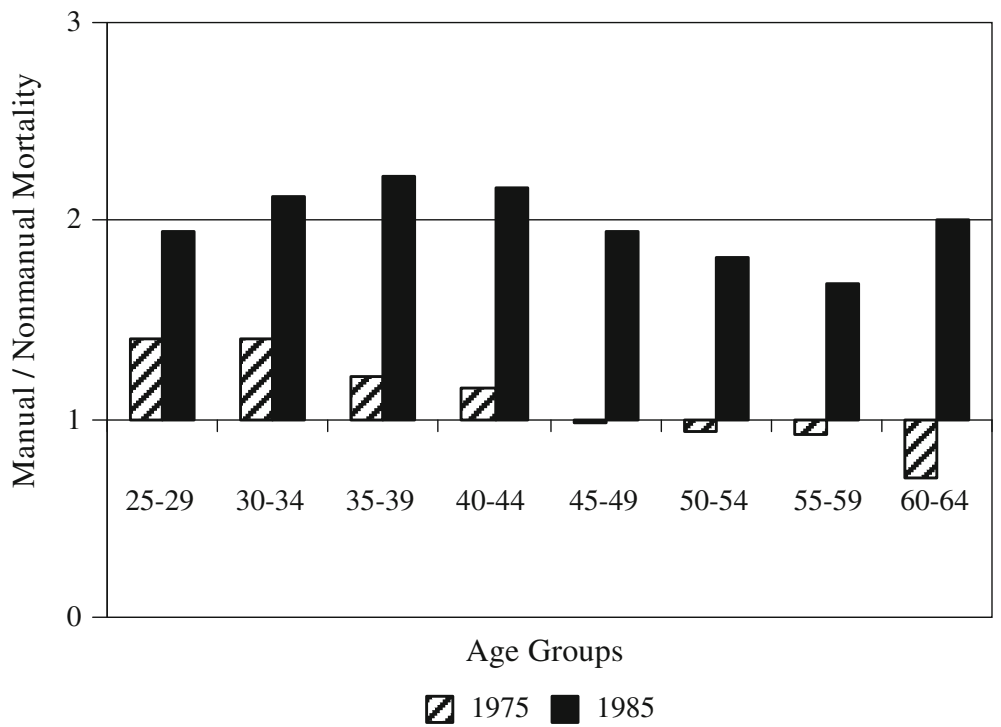

Fig. 7 Excess manual mortality-Bulgaria. Source: data from Carlson and Tsvetarsky 1994. Concentration of rising Bulgarian mortality among manual workers. Sociology and Social Research 76(2):81-85

\section{Conclusion}

Occupational contrasts in mortality from several national case studies are consistent with our hypothesis that state socialist development policy and its labor force consequences helped to produce the state socialist mortality syndrome. International comparative results for the state socialist and market capitalist halves of Europe's periphery also are consistent with the same hypothesis. Each approach provides independent empirical support for our macro-structural explanation.

Of course, we do not claim to have "proved" that our suggested explanation is true. We believe that simply establishing the basic plausibility of a new, systematic structural-level framework for explaining these mortality trends is by itself a valuable contribution to our understanding of one of the most arresting demographic trends in the twentieth century. State socialist development policies emphasizing industrial employment at the expense of the service sector created conditions that appeared consistently in the right times and places to explain subsequent rises in working-age male mortality, while countries and population groups not facing the brunt of these policies show stability or even improvement in survival rates.

Doubtless there can be other tests of related hypotheses. One of the ways that an exploratory hypothesis like ours can be valuable is in suggesting additional patterns to investigate. For example, case studies might determine whether mortality increases actually were concentrated among manual workers who did move from agriculture, as opposed to those who lived and worked in the urban industrial milieu all their lives. Information on place of birth, if available in death registration data, would be critical to such an inquiry. If the industry/service employment ratio is an 
important determinant of other, more proximate conditions in the lives of working adults, then it also ought to be possible to find the same pattern in other historical settings. Analogous mortality patterns may have been generated by quite different political and/or economic processes (Hammond and Hammond 1949; Rosefielde 1983; Matossian 1985; McCord and Freeman 1990; Abdala et al. 2000). Continued future changes in the industry/service ratio also should have other implications for survival trends.

Another important elaboration of this state socialist mortality syndrome thesis should investigate causes of death. The case studies of Hungary, Bulgaria, Latvia and other regions in the former USSR noted above already provide some evidence that mortality increases were concentrated in cause categories that are consistent with this general thesis, but further investigation could strengthen or undermine the argument. Further research also might follow the lead of Cockerham et al. (2002) who have shown that more than a decade after the collapse of state socialism, people more in favor of a return to the old Soviet state socialist system in the former Soviet Union have more destructive health habits including problematic diet, lack of exercise and consumption of toxins such as alcohol and tobacco.

Doubtless other kinds of hypotheses and empirical tests of them will occur to others in the future. Even if the theoretical link proposed here might eventually collapse under the weight of accumulated evidence, if it moves forward the search for a better understanding of the determinants of human survival it will have served its purpose.

Open Access This article is distributed under the terms of the Creative Commons Attribution Noncommercial License which permits any noncommercial use, distribution, and reproduction in any medium, provided the original author(s) and source are credited.

\section{References}

Abdala, F., Geldstein, R., \& Mychaszula, S. (2000). Economic restructuring and mortality changes in Aregentina: Is there any connection? In G. A. Cornia \& R. Paniccia (Eds.), The mortality crisis in transitional economies. Oxford: Oxford University Press.

Anderson, B., \& Silver, B. (1986). Infant mortality in the Soviet Union: Regional differences and measurement issues. Population and Development Review, 12, 705-738.

Anderson, B., \& Silver, B. (1989). The changing shape of Soviet mortality, 1958-1985: An evaluation of old and new evidence. Population Studies, 43(2), 243-266.

Andorka, R., \& Harcsa, I. (1983). Changes in village society during the last ten years. New Hungarian Quarterly, 24(92), 1-15.

Andreev, E. M., Hoffmann, R., Carlson, E. D., Shkolnikov, V. M., \& Kharkova Tatjana, L. (2009). Concentration of working-age male mortality among manual workers in urban Latvia and Russia, 1970-1989. European Societies, 11(8), 161-185.

Bernstam, M. S., \& Carlson, E. (1988). Neonatal and post-neonatal components of Soviet infant mortality trends: A note on bureaucratic irrelevance. Hoover Institution Working Papers in International Studies, No. 9.

Boleslawski, L. (1985). Differences in mortality among generations as a result of the world wars [Roznice w umieralnosci miedzy generacjami jako skutek wojen swiatowych]. Studia Demograficzne, 82(4), 51-71.

Bourgeois-Pichat, J. (1985). Recent changes in mortality in industrialized countries. In J. Vallin \& A. Lopez (Eds.), Health policy, social policy and mortality prospects. Liege: Ordina-IUSSP. 
Carlson, E. (1989). Concentration of rising Hungarian mortality among manual workers. Sociology and Social Research, 73(3), 119-128.

Carlson, E., \& Bernstam, M. S. (1992). Population and resources under the socialist economic system. Population and Development Review, 15(Supplement), 374-407.

Carlson, E., \& Tsvetarsky, S. (1992). Concentration of rising Bulgarian mortality among manual workers. Sociology and Social Research, 76(2), 81-84.

Carlson, E., \& Tsvetarsky, S. (1994). Rising Bulgarian infant mortality: Fact or artefact? In Child health and mortality in Europe: Chaire Quetelet 1994 (pp. 469-473). Institut de Démographie/École de Santé Publique, Louvaine-la-Neuve: Academia-Bruylant/L'Harmattan.

Carlson, E., \& Watson, M. (1990). The family and the state: Rising Hungarian death rates. In J. Mogey (Ed.), Aiding and aging: The coming crisis in support for the elderly by kin and state (pp. 135-160). New York: Greenwood Press.

Caselli, G. (1991). The quest for an interpretation of mortality differences: Socioeconomic background and adult mortality. In: INED. socioeconomic differential mortality in industrialized societies (pp. 229-41). Paris: CICRED.

Chandler, A. D., Jr. (1980). Industrial revolutions and institutional arrangements. Bulletin of the American Academy of Arts and Sciences, 33, 40-45.

Cockerham, W. C. (1997). The social determinants of the decline of life expectancy in Russia and Eastern Europe: A lifestyle explanation. Journal of Health and Social Behavior, 38(2), 117-130.

Cockerham, W. C. (2005). Health lifestyle theory and the convergence of agency and structure. Journal of Health and Social Behavior, 46(1), 51-67.

Cockerham, W. C., Christine Snead, M., \& DeWaal, D. F. (2002). Health lifestyles in Russia and the socialist heritage. Journal of Health and Social Behavior, 43(1), 42-55.

Compton, P. (1985). Rising mortality in Hungary. Population Studies, 39, 71-76.

Conner, W. (1991). The accidental proletariat. Princeton: Princeton University Press.

Cooper, R. (1985). Smoking and health in the Soviet Union and Eastern Europe. New York State Journal of Medicine, 85(7), 413-415.

Cooper, R., \& Schatzkin, A. (1982). The pattern of mass disease in the USSR: A product of socialist or capitalist development? International Journal of Health Services, 12(3), 459-480.

Cooper, R., Schatzkin, A., \& Sempos, C. (1984). Rising death rates among Polish men. International Journal of Health Services, 14, 289-302.

Cooper, R., \& Sempos, C. (1984). Recent mortality patterns associated with economic development in Eastern Europe and the USSR. Journal of the National Medical Association, 76(2), 163-166.

Cornia, G., \& Paniccia, R. (2000). Mortality crisis of the early 1990s: A historical perspective. In A. G. Cornia \& R. Paniccia (Eds.), The mortality crisis in transitional economies. Oxford: Oxford University Press.

Daric, J. (1951). Mortality, occupation and socioeconomic status. In U.S. vital statistics: Special reports, selected studies (Vol. 33, No. 10, pp. 175-87). Washington: National Office of Vital Statistics.

Deacon, B. (1984). Medical care under state socialism. International Journal of Health Services, 14(3), 453-480.

Dinkel, R. (1985). The seeming paradox of increasing mortality in a highly industrialized nation: The example of the Soviet Union. Population Studies, 39, 87-97.

Dupaquier, J. (1984). La contre-offensive de la mortalite dans le dernier quart du Xxe siecle. Histoire, Economie et Societe, 3(3), 473-490.

Feinstein, J. S. (1993). The relationship between socioeconomic status and health: A review of the literature. Milbank Quarterly, 71(2), 279-322.

Feshbach, M. (1982). The Soviet Union: Population trends and dilemmas. Population Bulletin 37(3).

Forster, D. P., \& Jozan, P. (1990). Health in Eastern Europe. Lancet, 335, 458-460.

Giersdorf, P., \& Schuler, H. (1984). Tendenzen der Mortalitaet mannlicher Personen im mittleren Alter [Trends in the mortality of middle-aged males]. Zeitschrift fur Artzliche Fortbildung, 78(3), 83-87.

Golemanov, N., Rusev, B., Septliev, D., \& Khristov, E. (1984). Smurtnost na naselenieto v Bulgaria 1964-2000 [Mortality of the population in Bulgaria 1964-2000]. Meditsina I Fizkultura (Sofia) 237.

Griva, K., \& Sugareva, M. (1984). Razvitie na smurtnostta v Bulgaria I v nyakoi drugi strani na Evropa pres 1995-1980 godini [The development of mortality in Bulgaria and some other European countries in the years 1955-1980]. Naselenie (Sofia), 2(4), 74-90.

Hammond, J. L., \& Hammond, B. (1949). The town labourer: 1760-1830. London: Guild Books.

Hoehn, C. (1981). Les différences internationales de mortalité infantile: Illusion ou réalité? Population, 36(4-5), 791-816. 
Hoehn, C., \& Pollard, J. (1991). Mortality in the two Germanys in 1986 and trends 1976-1986. European Journal of Population, 7, 1-28.

Hoffmann, R. (2008). Socioeconomic differences in old age mortality. Dordrecht: Springer.

Horiuchi, S. (1983). The long-term impact of war on mortality: Old-age mortality of the first world war survivors in the Federal Republic of Germany. Population bulletin of the United Nations, No. 15. New York: United Nations.

Ivanov, S., \& Echenique, V. (2000). Demographic situation and mortality trends in Russia. In T. Kucera, et al. (Eds.), New demographic faces of Europe (pp. 287-304). Berlin: Springer Verlag.

Jozan, P. (1986). a budapesti halandosagi kulonbsegek okologiai vizsgalata 1980-1983 [an ecological study on the mortality differences in Budapest 1980-1983]. Demografia, 29(2-3), 193-240.

Jozan, P. (1989). Some features of mortality in postwar Hungary: The third epidemiological transition. Cahiers de Sociologie et de Demographie Medicales, 29(1), 21-42.

Klinger, A. (1987). A halandosag tarsadalmi foglalkozasi kulongbsegei magyarorszagon [Socioeconomic mortality differentials in Hungary]. Demografia, 30(2-3), 240-272.

Kornai, J. (1959). Overcentralization in economic administration. Oxford: Oxford University Press.

Kornai, J. (1982). Growth, shortage and efficiency. Berkeley: University of California Press.

Kornai, J. (1992). The socialist system: The political economy of communism. Princeton: Princeton University Press.

Kunitz, S. J. (1987). Explanations and ideologies of mortality patterns. Population and Development Review, 13(3), 379-408.

Kunst, A. E., \& Mackenbach, J. P. (1994). The size of mortality differences associated with educational level in nine industrial countries. American Journal of Public Health, 84(6), 932-937.

Madai, L. (1980). A 40-64 eves ferfiak halalozasi tobblete Europaban [Mortality surplus of males aged 40-64 in Europe]. Demografia, 23(1), 72-96.

Makala, P., Valkonen, T., \& Martelin, T. (1997). Contribution of deaths related to alcohol use to socioeconomic variation in mortality. British Medical Journal, 315, 211-216.

Mare, R. D. (1990). Socioeconomic careers and differential mortality among older men in the United States. In J. Vallin, S. D’Souza, \& A. Palloni (Eds.), Measurement and analysis of mortality: New approaches (pp. 362-387). Oxford: Clarendon Press.

Marmot, M. G., Shipley, M. J., \& Rose, G. (1984). Inequalities in death-specific explanations of a general pattern? Lancet, 323(8384), 1003-1006.

Matossian, M. (1985). Death in London 1750-1909. Journal of Interdisciplinary History, 16(2), $183-197$.

McCord, C., \& Freeman, H. (1990). Excess mortality in Harlem. In P. Conrad \& R. Kern (Eds.), Sociology of health and illness (pp. 35-42). New York: St. Martin's Press.

McKee, M., \& Shkolnikov, V. (2001). Understanding the toll of premature death among men in eastern Europe. British Medical Journal, 523, 1051-1055.

McKee, M., Shkolnikov, V. M., \& Leon, D. A. (2001). Alcohol is implicated in the fluctuations in cardiovascular disease in Russia since the 1980 s. Annals of Epidemiology, 11(1), 1-6.

McQueen, D., \& Siegrist, J. (1982). Social factors in the etiology of chronic disease: An overview. Social Science and Medicine, 16, 353-367.

Meslé, F. (2004). Mortality in Central and Eastern Europe: Long term trends and recent upturns. Demographic Research Special Collection, 2(3), 45-75.

Meslé, F., Shkolnikov, V., \& Vallin, J. (1993). Mortality by cause in the USSR in 1970-87. European Journal of Population, 8(4), 218-308.

Minev, D., Dermendjieva, G., \& Mileva, N. (1990). The Bulgarian country profile: The dynamics of some inequalities in health. Social Science Medicine, 31(8), 837-846.

Moore, W. (1945). Economic demography of eastern and southern Europe. Geneva: League of Nations.

Okolski, M. (1985). L'accroissement de la mortalite durant les annees recentes en Pologne [The rise in mortality in recent years in Poland]. Cahiers de Sociologie et de Demographie Medicales, 25(1), 33-54.

Okolski, M. (1987). Male mortality trends in eastern and western Europe. Studia Demograficzne, 72(2), $3-28$.

Okubo, M. (1981). Increase in mortality of middle-aged males in Japan. Tokyo: Nihon University Population Research Institute.

Pamuk, E. (1985). Social class inequality in mortality from 1921 to 1972 in England and Wales. Population Studies, 39(1), 17-31.

Poikolainen, K. (1995). Alcohol and mortality: A review. Journal of Clinical Epidemiology, 48, 455-465. 
Preston, S. H., \& Elo, I. T. (1995). Are educational differentials in adult mortality increasing in the United States? Journal of Aging and Health, 7(4), 476-496.

Rosefielde, S. (1983). Excess mortality in the Soviet Union: A reconsideration of the demographic consequences of forced industrialization 1929-1949. Soviet Studies, 35(3), 385-409.

Rychtaříková, J. (2004). The case of the Czech Republic: Determinants of the recent favourable turnover in mortality. Demographic Research Special Collection, 2(5), 105-138.

Schoen, R. (1970). The geometric mean of the age-specific death rates as a summary index of mortality. Demography, 7, 317-324.

Shandra, J. M., London, B., \& Williamson, J. B. (2003). Environmental degradation, environmental sustainability, and overurbanization in the developing world: A quantitative, cross-national analysis. Sociological Perspectives, 46(3), 309-329.

Shkolnikov, V. M., Cornia, G. A., Leon, D. A., \& Meslé, F. (1998a). Causes of the Russian mortality crisis: Evidence and interpretations. World Development, 26, 1995-2011.

Shkolnikov, V. M., Leon, D. A., Adamets, S., Deev, A., \& Andreev, E. (1998b). Educational level and adult mortality in Russia: An analysis of routine data 1979 to 1994. Social Science and Medicine, 47, 357-369.

Smelser, N., \& Lipset, S. M. (1967). Social structure and mobility in economic development. Chicago: University of Chicago Press.

Stocks, P. (1938). The effects of occupation and its accompanying environment on mortality. Journal of the Royal Statistical Society, 101, 669-708.

Vacek, M. (1969). Mortality trends in Czechoslovakia. U.S. Vital and Health Statistics Series 3, Number 13. Department of Health, Education and Welfare.

Valkonen, T. (1993). Problems in the international comparisons of socioeconomic differences in mortality. Social Science and Medicine, 36, 409-418.

Valkovics, E. (1984). L'evolution recente de la mortalite dans les pays de l'Est: essai d'explication a partir de l'exemple hongrois. Espace, Populations, Societies, 10(3), 141-168.

Velkoff, V. A., \& Miller, J. E. (1995). Trends and differentials in infant mortality in the Soviet Union, 1970-90: How much is due to misreporting? Population Studies, 49(2), 241-258.

Vielrose, E. (1984). Kilka uwag o vozmieszczeniu terytorialnym przyczynzgonow w Polsce [Some remarks about the spatial distribution of causes of death in Poland]. Studia Demograficzne, 78(4), 87-94.

Volgyes, I. (1980). Dynamic change: Rural transformation, 1945-1975. In J. Held (Ed.), The modernization of agriculture: Rural transformation in Hungary, 1848-1975 (pp. 351-508). New York: Columbia University Press.

Yang, Y. (2008). Trends in U.S. adult chronic disease mortality, 1960-1999: Age, period, and cohort variations. Demography, 45(2), 387-416.

Yang, Y., Fu, W. J., \& Land, K. C. (2004). A methodological comparison of age-period-cohort models: The intrinsic estimator and conventional generalized linear models. Sociological Methodology, 34, 75-110.

Yang, Y., Fu, W. J., Schulhofer-Wohl, S., \& Land, K. C. (2008). The intrinsic estimator for age-periodcohort analysis: What it is and how to use it. American Journal of Sociology, 113(6), 1697-1736. 